\title{
Microalterations in the third eyelid gland of dogs with keratoconjunctivits sicca secondary to distemper
}

\author{
[Microalterações da glândula terceira pálpebra em cães com cinomose \\ e acometido por ceratoconjuntivite seca] \\ F.L.C. Brito ${ }^{1}$, V.A. Silva Júnior ${ }^{2}$, F.C.L. Maia ${ }^{2}$, J.R. Pereira Junior ${ }^{2}$, J.L. Laus $^{3}$ \\ ${ }^{1}$ Unidade Acadêmica de Garanhuns - UFRPE \\ Av. Bom Pastor, $\mathrm{s} / \mathrm{n}$ \\ 55296-901 - Garanhuns, PE \\ ${ }^{2}$ Departamento de Medicina Veterinária - UFRPE - Recife, PE \\ ${ }^{3}$ Faculdade de Ciências Agrárias e Veterinárias - UNESP - Jaboticabal, SP
}

\begin{abstract}
Keratoconjunctivitis sicca is characterized by qualitative or quantitative abnormalities in the aqueous component of the tear film and is frequent in dogs with distemper. Twenty-eight third eyelid glands of end-stage dogs that died from distemper were analyzed by light microscopy. Keratoconjunctivitis sicca was diagnosed based on ophthalmic findings regarding alterations in the ocular surface and by the Schirmer tear test. The excised glands were fixed in $10 \%$ buffered formalin and processed for embedding in paraffin. The blocks were cut into $4 \mu \mathrm{m}$ sections and the sections were stained with hematoxylin-eosin and Masson's trichrome. Analysis revealed tubuloacinar gland atrophy, thickening of connective tissue, and mild to intense inflammatory exudation mainly characterized by the presence of plasma cells and histiocytes and by compensatory hypertrophy of some glands. The glandular lumen was hypertrophied and contained shedded epithelial cells, polymorphonuclear cells and red blood cells, in addition to mucus.
\end{abstract}

Keywords: dog, distemper, keratoconjunctivitis sicca, third eyelid gland

\section{RESUMO}

Analisaram-se, à microscopia óptica, 28 glândulas da terceira pálpebra de cães, que morreram com cinomose. O diagnóstico de ceratoconjuntivite seca baseou-se nas alterações da superfície ocular e no teste da lágrima de Schirmer. À histologia, visibilizaram-se atrofia tubuloacina, espessamento do tecido conjuntivo e exudação inflamatória de leve a intensa com presença de plasmócitos, de histiócitos e por hipertrofia compensatória de algumas glândulas. O lume das glândulas encontrava-se hipertrofiado contendo células epiteliais descamadas, polimorfonucleares e hemácias, além de muco.

Palavras-chave: cão, cinomose, ceratoconjuntivite seca, glândula terceira pálpebra

\section{INTRODUCTION}

Keratoconjunctivitis sicca (KCS) is a usually chronic inflammatory disease which frequently affects dogs, and is characterized by qualitative or quantitative deficiency of the aqueous component of the tear film. Complications and developments can cause blindness (Gelatt, 1991; Barros et al., 1992; Moore, 1999). The tear film consists of three

Recebido em 23 de dezembro de 2004

Aceito em 5 de fevereiro de 2007

e-mail: fabiobrito@click21.com.br distinct layers: lipid, aqueous and mucous layer. Since there is a close interaction between the aqueous, lipid and mucous components, abnormalities in the quantity or quality of these components may alter tear film dynamics and compromise its function (Samuelson, 1999; Moore, 1999).

The aqueous layer is produced by the main lacrimal gland $(70 \%)$ and by the third eyelid gland $(30 \%)$, 
the oily layer is secreted by the meibomian glands, and the mucous layer is produced by goblet cells of the conjunctiva (Saito et al., 2001).

The clinical symptoms of KCS are variable and depend on the severity of the disease, rate of development and chronicity. Initially, the eyes appear red and inflamed, with excessive mucous or mucopurulent ocular secretion. In more severe cases, the ocular surface loses its brightness and the conjunctiva becomes hyperemic, and in the most severe cases new vessels, pigments and corneal ulcers might be present (Moore, 1999; Saito et al., 2001).

The etiological causes of KCS are variable, including chronic blepharoconjunctivitis, congenital acinar hypoplasia, systemic therapy with sulfonamides or topical atropine, metabolic disorders, neuropathies, immunomediated diseases, and infectious causes (Moore, 1999). Among diseases of viral origin that affect dogs, distemper is the most prevalent. Although showing a higher incidence in young dogs aged 3 to 6 months, the disease affects animals of all ages (Swango, 1996). The ophthalmic signs usually observed in animals with distemper are associated with bilateral conjunctivitis which progresses from serous to mucopurulent, symptoms of KCS and chorioretinitis (Martins and Stiles, 2003).

Despite the large number of studies regarding the etiology, symptoms, diagnosis and treatment of diseases affecting the lacrimal and third eyelid superficial glands of dogs (Morgan and Abrans, 1991; Barros et al., 1992), little is known about their pathogenesis in animals with distemper. The objective of the present study was to characterize the light microscopic alterations that occur in the third eyelid gland of dogs with KCS secondary to distemper.

\section{MATERIAL AND METHODS}

Fourteen male and female dogs of varied breeds, ranging in age from 2 to 5 months, with symptoms compatible with distemper, which died naturally, were studied. The diagnosis of KCS was made based on ophthalmic findings and the results of the Schirmer tear test (STT), with scores of $5 \mathrm{~mm} / \mathrm{min}$ or less being considered positive. The third eyelid glands were collected, fixed in $10 \%$ buffered formalin and processed for embedding in paraffin. The blocks were cut into $4 \mu \mathrm{m}$ sections with a microtome and the sections were stained with hematoxylin-eosin and Masson's trichrome and analyzed by light microscopy.

\section{RESULTS}

The most consistent clinical signs compatible with distemper were nasal secretion, vomiting and diarrhea, hyperthermia, myoclonia, motor incoordination, and seizures. Ophthalmic findings included conjunctival hyperemia, episcleral congestion, lackluster ocular surface, notably mucoid ocular secretion, edema, corneal neovascularization, and an STT score of $5 \mathrm{~mm} / \mathrm{min}$ or less.

Histopathological analysis revealed connective tissue thickening and a mild to intense inflammatory exudative process, with a predominance of plasma cells and histiocytes, in all glands (Fig. 1). Atrophy of the tubuloacinar glands was observed in all dogs and preceded in some cases the inflammatory symptoms (Fig. 2). Compensatory hypertrophy of some glands was noted. In various animals, the glandular lumen was hypertrophied, containing shedded epithelial cells, polymorphonuclear cells and red blood cells, in addition to excess mucus which partially or completely obstructed the lumen (Fig. 3). Fibroblast hyperactivity, with active mucussecreting cells, was observed in the thickened interlobular connective tissue. Dead keratinocytes and intermingled inflammatory cells were also identified (Fig. 4). Atrophy of the tubuloacinar glands associated the metaplasia of the tubular glandular epithelium were observed in some dogs.

\section{DISCUSSION}

The clinical signs observed in dogs with distemper comprise respiratory, gastrointestinal, nervous and ocular alterations (Swango, 1996), as found in the present study. Ophthalmic manifestations such as conjunctivitis and KCS have been frequently reported in animals with distemper (Boldy and Clerc, 1996) and were also observed in the present study. 


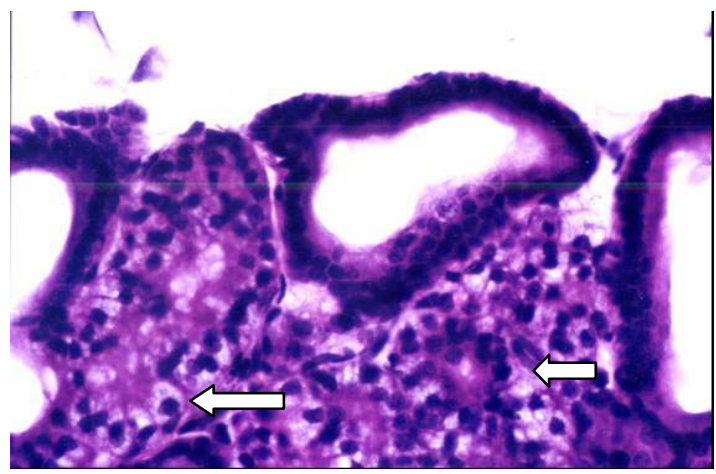

Figure 1. Photomicrography of third eyelid gland of dog with canine distemper. Observe the intense inflammatory exudation surrounding the tubuloacinar glands, mainly of plasmocytes (wide arrow) and histiocytes (large arrow). 400x. HE.

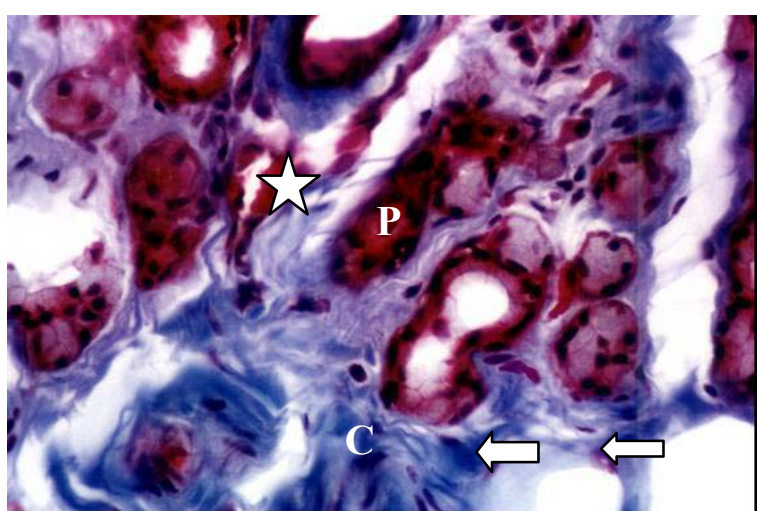

Figure 3. Photomicrography of third eyelid gland of dog with canine distemper. Observe the red blood cells (white star), intratubular polimorphonuclear cells (P) spreading of connective tissue (C) and active fibroblasts (large arrow). 400x. Masson's trichrome.

KCS is an important and frequent ocular disorder in dogs. However, the resulting ophthalmic symptoms vary according to the duration of the disease and include conjunctival congestion, mucoid or mucopurulent ocular secretion, variable degrees of keratitis including ulcerative keratitis, neovascularization, and pigmentation (Barros et al., 1992; Martins and Stiles, 2003).

In the present study, tubuloacinar gland atrophy, with obstruction of the lumen with mucus, and dacryoadenitis characterized by a polymorphonuclear cell infiltrate predominated among the lesions affecting the third eyelid gland. According to Martins and Stiles (2003), the distemper virus can induce inflammation of the lacrimal gland, which is characterized by marked infiltration of mononuclear cells and

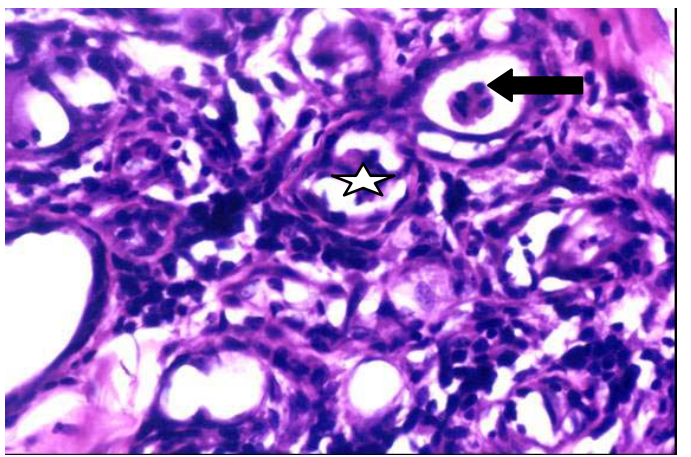

Figure 2. Photomicrography of third eyelid gland of dog with canine distemper. Observe the atrophy of the tubuloacinar gland (star) and intratubular mononuclear cells (arrow). 400x. HE.

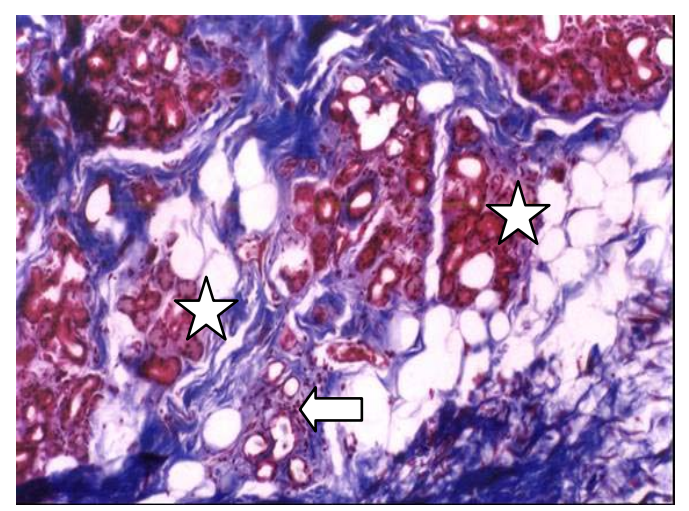

Figure 4. Photomicrography of third eyelid gland of dog with canine distemper. Observe intratubular polimorphonuclears (arrow) and partial or total obstruction of the tubuloacinar glands (stars). 100x. Masson's trichrome.

neutrophils, as well as by degenerative alterations in the glandular tissue.

Intratubular and connective tissue neutrophils may represent secondary bacterial infection (Kaswan et al., 1984). Plasma cells were observed in the glands studied here. Their presence indicates a local immune response because these cells are responsible for the local production of $\operatorname{IgA}$, the predominant immunoglobulin in the tear film (Martins et al., 1988; Dugan et al., 1992).

In cases of coronavirus infection, chronic active inflammatory lesions, as well as epithelial hyperplasia and metaplasia of the inter- and intralobular ducts, have also been reported 
(Kaswan et al., 1984) and were observed in the present study in dogs with distemper.

Gao et al. (1998) reported the occurrence of extensive lymphocytic infiltration, concomitantly with signs of tissue injury, in the lacrimal glands and conjunctiva of animals with KCS, suggesting that in these cases inflammation is the result, at least in part, of the absence of apoptosis in this cell type.

Autoimmune mechanisms have been implicated, notably in the progression of tissue derangement. The release of antigens present in tissues may result in autoimmunity. The lumen of the lacrimal duct and the membranes of the acinar epithelium are considered to be immuneprivileged sites, normally protected by the bloodtear barrier. Since antigens are isolated in the conjunctival tissue, alterations in the blood-tear barrier lead to tissue injury and, consequently, to an inflammatory response (Shabo et al., 1973). This mechanism might be involved in the genesis of the inflammatory process of KCS in dogs with distemper.

Thickening of interlobular connective tissue is caused by the presence of active fibroblasts which, in turn, synthesize large amounts of matrix and stimulate mucus production, resulting in interstitial fibrosis. The suppression of activated fibroblasts during the initial course of the disease would prevent progressive conditions of tear film abnormalities (Ogawa et al., 2001). The shedded cells also observed in the connective tissue possibly result from metaplasia of the glandular epithelium.

Squamous metaplasia of the tubular epithelium was a common finding in the present study. In some species, vitamin A deficiency may induce atrophy of the glandular epithelium, followed by squamous metaplasia, thus increasing susceptibility to secondary bacterial infection. However, vitamin A deficiency is probably not a common cause of $\mathrm{KCS}$ in dogs since the commercial rations are nowadays supplemented with this vitamin (Gelatt, 1981; Sommer, 1982).

Compensatory hypertrophy of the tubuloacinar glands has not been previously reported but was observed in the present study. We believe that this complication is due to the large number of obstructed tubuloacinar glands and possibly represents a condition associated with $\mathrm{KCS}$ in dogs with distemper.

\section{CONCLUSION}

The histological alterations observed in the third eyelid gland of dogs in which dacryoadenitis predominated demonstrate that glandular atrophy and obstruction and inflammatory exudation are the main causes of KCS secondary to distemper.

\section{REFERENCES}

BARROS, P.S.M.; SAFATLE. A.V.M.; ALVARENGA, J. et al. Aspectos clínicos da ceratoconjuntivite seca em cães. Estudo retrospectivo em 223 casos. ARS Vet., v.8, p.614, 1992.

BOLDY, K.L.; CLERC, B. Manifestações oculares da afecção sistêmica. In: ETTINGER, S.J. Manual de medicina interna veterinária, 1.ed. São Paulo: Manole, 1996. p.52-58.

DUGAN, S.J.; SEVERIN, G.A.; HUNGERFORD, L.L. et al. Clinical and histologic evaluation of the prolapsed third eyelid gland in dogs. J. Am. Vet. Med. Assoc., v.201, p.1861-1867, 1992.

GAO, J.; GELBER-SCHWALB, T.A.; ADDEO, J.V. et al. Apoptosis in the lacrimal gland and conjunctiva of gry eye dogs. Cornea, v.17, p.654-663, 1998.

GELATT, K.N.; GWIN, R.M. Canine lacrimal and nasolacrimal systems. In: GELATT, K.N. Veterinary Ophthalmology. Philadelphia, Lea \& Febiger, 1981. p.309-329.

GELATT, K.N. Canine lacrimal and nasolacrimal diseases. In: GELATT, K.N. (Ed). Veterinary ophthalmology. Philadelphia: Lea \& Febiger, 1991. p.276-289.

KASWAN, R.L.; MARTINS, C.L.; CHAPMAN Jr., W.L. Keratoconjunctivitis sicca: Histopatologic study of nictitanting mambrane and lacrimal glands from 28 canine cases. Am. J. Vet. Res. v.45, p.112-118, 1994.

MARTINS, C.L.; MUNNELL, J.; KASWAN, R. Normal ultrastructure and histochemical characteristics of canine lacrimal glands. Am. J. Vet. Res., v.49, p.1566-1572, 1988. 
MARTINS, C.L.; KASWAN, R. Distemper associated keratoconjunctivitis sicca. J. Am. Anim. Hosp. Assoc., v.21, p. 355-359, 1985.

MARTINS, C.L.; STILES, J. Manifestações oculares de doenças sistêmicas. In: GELATT, K. N. Manual de oftalmologia veterinária. São Paulo: Manole, 2003. 594p.

MOORE, C.P. Diseases and surgery of the lacrimal secretory system. In: GELATT, K.N. (Ed.) Veterinary Ophthalmology. Philadelphia: Lea \& Febiger, 1999. p. 583-607.

MORGAN, R.V.; ABRAMS, K.L. Topical administration of ciclosporine for treatment of keratoconjuntivitis sicca in dogs. J. Am. Vet. Med. Assoc., v.199, p.1043-1046, 1991

OGAWA, Y.; YAMAZAKI, K.; KUWANA, M. et al. A significant role of stromal fibroblast in radidly progressive dry eye in pacinets with chronic GVHD. Invest. Ophthalmol. Vis. Sci., v.42, p.11-119, 2001.
SAITO, A.; IZUMISAWA, Y.; YAMASHITA, $\mathrm{K}$. et al. The effect of third eyelid gland removal on the ocular surface of dogs. Vet. Ophthalmol., v.4, p.13-18, 2001.

SAMUELSON, D.A. Ophthalmic anatomy. In: GELATT, K.N. (ed) Veterinary ophthalmology. Philadelphia: Lea \& Febiger, 1999. p.31-150.

SHABO, A.L.; KENYON, K.R.; FRANKLIN, R.M. Electron microscopic localization of a blood-tear barrier to tracer protein in the primate lacrimal gland. Lab. Invest., p.185-193, 1973.

SOMMER, A. Tear production in vitamin A responsive xerophthalmia. Am. J. Ophthalmol., v.93, p.84-87, 1982.

SWANGO, L.J. Moléstias virais caninas. In: ETTINGER, S.J. Manual de medicina interna veterinária. São Paulo: Manole, 1996. p.154155. 